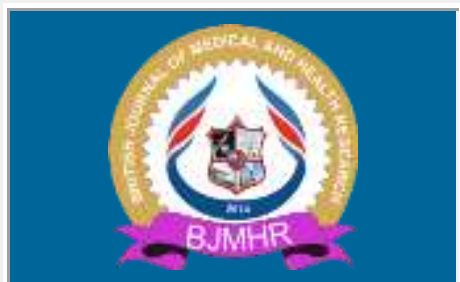

\title{
BJMHR
}

British Journal of Medical and Health Research Journal home page: www.bjmhr.com

\section{Anthelmintic Activity of Ethanolic Extract of Streblus Asper against Pheretima Posthuma}

\author{
Anil Kumar*, K. Saravanan \\ Bhagwant University, Shikar Road, Ajmer, Rajasthan, India
}

\begin{abstract}
Among the most common infections of digestive system in human beings are helminth infections. In developing countries they pose a large threat to the society. Such parasitic diseases cause severe morbidity, including lymphatic Filariasis, onchoserciasis and schistosomiasis. The present paper deals with anthelmintic activity of leaves of Streblus asper belonging to family Moraceae, a potential medicinal plant. The plant is used in traditional medicine for folk medicine for the treatment of different ailments such as Filariasis, Leprosy, Tooth ache, Diarrhea, Dysentery, and Cancer. The ethanolic and aqueous extracts were evaluated for its anthelmintic activity against adult Indian earth Worms (Pheretima posthuma). Three concentrations $(25,50$ and $100 \mathrm{mg} / \mathrm{ml})$ of each extract were studied, which involved for the determination of time of paralysis and time of death of the test worms. It was found that ethanolic extracts exhibited significant anthelmintic activity while aqueous extract show least activity. The bioassay involved determination of the time of paralysis and time of death control.
\end{abstract} Piperazine citrate $(10 \mathrm{mg} / \mathrm{mL})$ was used as standard reference drug Keywords: Anthelmintic activity, Pheretima posthuma, Piperazine citrate, Streblus asper, 


\section{INTRODUCTION}

Streblus asper (family-Moraceae) is a small tree which is indigenous to tropical countries such as India, Srilanka, Philippines and Thailand. In India it is distributed in the Himalayas from Himachal Pradesh to West Bengal and in hills and plains of Assam and Tripura. It is also found in the drier parts of India. Various parts of this plant are used in Ayurveda and other folk medicine for the treatment of different ailments such as Filariasis, Leprosy, Tooth ache, Diarrhea, Dysentery, and Cancer. Root is used as an application to the unhealthy ulcers and sinuses, and as antidote to snakebite, in epilepsy and obesity. Stem is used in toothache, Stem bark is given in fever, dysentery, diarrhea, stomach ache, urinary complaints, piles, edema and wounds. Decoction is effective against lymphodema, chylurea, and other effects of Filariasis. Leaves are used in eye complaints; milky juice is used as antiseptic, astringent, applied to chapped hand and sore feet, in pneumonia and swells of cheeks. The other part which is not specified is used in cancer, cholera, colic, diarrhea, dysentery, epilepsy and inflammatory swellings. The branch of Streblus asper has been used as tooth brush for strengthening teeth and gums. Streblus asper extracts thus has the potential for being used as a natural product for controlling dental carries. Streblus asper is a rigid shrub or gnarled evergreen tree; bark light grey and a rich source of cardiac glycosides. More than 20 cardiac glycosides from the root bark of Streblus asper have been reported and were able to structurally characterize about 15 such compounds, kamloside, asperosides, trebloside, glucokamloside, glucostrebloside, Strebloside, and $\beta$-sitosterol were reported.

\section{MATERIAL AND METHOD}

\section{Collection of Plant Material:}

The leaves of Streblus asper were collected in locally from local area of Azamgarh, UttarPradesh, India in the month of September and were authenticated by Professor Dr. N. K. Dubey Taxonomist, centre of Advanced study in botany, institute of science, Banaras Hindu University, Varanasi (India) as Streblus asper (Moraceae) leaves. A voucher specimen has been kept in the herbarium (voucher specimen no. mora. 2019/1). Department of botany. The leaves were dried under shade and coarsely powdered.

\section{Drugs and chemicals}

All the chemicals and reagents were procured from S. D. Fine Chemicals (Mumbai, India). All the chemicals were of analytical grade. The drug Piperazine citrate was procured from Glaxo Smithkline Ltd, Mumbai.

\section{Preparation of extracts}

The Streblus leaves were cut into small pieces and air dried for 48-72 h. Dried leaves were ground into a fine powder. Coarsely powdered material (500 g) was extracted successively with 
ethanol and water by maceration process at room temperature for three days. Then all the extracts were filtered and concentrated with a rotary evaporator and kept in a refrigerator.

\section{Animal:}

Healthy adult Indian earthworms, Pheretima posthuma, due to its anatomical and physiological resemblance with the intestinal roundworm parasites of human beings were used in the present study. All earthworms were of approximately equal size $(15 \mathrm{~cm})$. They were collected from local moist place, washed and kept in water.

\section{Study of Anthelmintic activity}

The assay was performed on adult Indian earthworm Pheretima posthuma due to its anatomical and physiological resemblance with the intestinal round worm parasite of human being. Five groups of Indian earth worms each containing six earthworms approximately of equal size was used for the study. Each group of earth worms were tested with different extract conc. (25. 50 and $100 \mathrm{mg} / \mathrm{mL}$ ), distilled water (Control), and reference standard Piperazine citrate (10 $\mathrm{mg} / \mathrm{mL}$ in distilled water). Observations were made for the time taken for paralysis and death of individual worms. Time for paralysis was noted when no movement of any sort could be observed except when the worms were shaken vigorously. Time for death of worms were recorded after ascertaining that the worms neither moved when shaken vigorously nor when dipped in warm water at $50{ }^{0} \mathrm{C}$ followed with fading of their body color.

\section{RESULTS AND DISCUSSION}

Preliminary phytochemical screening of different extracts of leaves of Streblus asper revealed the presence of alkaloids, flavonoids, tannins and Saponins. Tannins and polyphenolic compounds were shown to produce anthelmintic activities. In the present study, it was observed that all the extracts of Streblus asper leaf have exhibited positive response to certain degree of anthelmintic activity. Extracts exhibited more potent activity at higher concentration (100 $\mathrm{mg} / \mathrm{mL}$ ) against Pheretima posthuma (earthworm). Evaluation of anthelmintic activity was compared with reference standard Piperazine citrate as shown in Table.1.

Table 1: Anthelmintic activity was compared with reference standard Piperazine citrate

\begin{tabular}{lllll}
\hline S. No & Extract & Conc. $(\mathbf{m g} / \mathbf{m l})$ & Paralysis $(\mathbf{m i n})$ & Death $(\mathbf{m i n})$ \\
\hline 1 & Vehicle & $\ldots \ldots \ldots \ldots$ & $\ldots \ldots \ldots \ldots . .$. & $\ldots \ldots \ldots \ldots . .$. \\
2 & Piperazine citrate & 10 & $19.36 \pm 0.87$ & $61 \pm 0.68$ \\
3 & Ethanolic & 25 & $18.16 \pm 0.65$ & $61.83 \pm 1.32$ \\
& & 50 & $11.32 \pm 0.51$ & $28.10 \pm 0.81$ \\
& & 100 & $5.47 \pm 0.40$ & $15.06 \pm 0.40$ \\
4 & Aqueous & 25 & $29.53 \pm 0.79$ & $86.83 \pm 1.72$ \\
& & 50 & $19.5 \pm 0.42$ & $42.83 \pm 1.16$ \\
& & 100 & $14 \pm 0.25$ & $33.66 \pm 1.43$ \\
\hline
\end{tabular}

Values are expressed as Mean $\pm \operatorname{SEM}(n=6)$ 


\section{REFERENCES}

1. K. D. Tripathi, Essentials of Medical Pharmacology, 6th Ed., Jaypee Brothers Medical Publishers, (P) Ltd. New Delhi (2008).

2. Dwivedi, S. Dwivedi, A. K. Sitoke, R. Patel and D. Jhade, Anthelmintic Activity of a Polyherbal Preparation, Ethnobotanical Leaflets., 13, 259-62 (2009).

3. S. N. Khadatkar, J. V. Manwar and N. S. Bhajipale, In Vitro Anthelmintic Activity of Root of Clitoria Ternatea Linn, Phcog. Mag., 4(13), (Suppl), 148-50 (2008).

4. R. G. Mali and R. R. Wadekar, In Vitro Anthelmintic Activity of Baliospermum Montanum Muell. Arg Roots, Indian J. Pharm. Sci., 131-133 (2008).

5. E. C. Bate-Smith, The Phenolic Constituents of Plants and their Taxonomic Significance, Dicotyledons, J. Linn. Soc. Bot., 58, 95-173 (1962).

6. Suwimol Taweechaisupapong, P. Klanrit. S. Singhara, W. Pitaiphat, S. Wongkham, In vitro inhibitory effect of Streblus asper leaf extract on adhesion of Candida albicans to human buccal epithelial cells, J. Ethnopharmacol, 2006:106,414-417.

7. Suwimol Taweechaisupapong, T. Choopan, S. Singhara, S. Shatrchaiwiwatana, S. Wongkham, The inhibitory effect of Streblus asper leaf extract on adhesion of Candida albicans to denture acrylic, J. Ethnopharmacol, 2005:96,221-226.

8. M.S. Hashim and K.S. Devi, Insecticidal action of the polyphenolic rich fractions from the stem barks of Streblus asper on Dysdercus cingulatus. Fitoterapia, 2003: 74, 670676.

9. Fiebig M, Duh CY, Pezzuto JM, Kinghorn AD, Farnsworth NR, Plant anti cancer agents, cardiac glycoside from Streblus asper, J of Nat Prod, 1985:48,981-85.

10. Mukherjee, K. and Roy, LN, The Chemical examination of Streblus asper leaves, Int J Crude Drug Res, 1983: 21, (4), 189-90.

11. Nazneen Parveen, K.C. Singhal, Nizam U.Khan and Parul Singhal, the Potential antifilarial activity of Streblus asper against Setaria cervi, Indian J. Pharmacol 1989 21: $16-21$.

12. Kirthikar K R and Basu B D, Indian Medicinal Plants, Dehradun, Bishen Singh Mahendra Pal Singh, 1935.

13. Aswar Manoj, Aswar Urmila,Watkar Bhagyashri.,et al. Anthelmintic activity of ficus bengalnensis. Int J Green Pharm,170-173,( 2008).

14. Deore SL, Khadabadi SS, Kamdi KS. et al, In vitro Anthelmintic activity of Cassia torra. Int J Chem Tech Res, 1: 177-179, (2009).

15. Martin RJ., Mode of action of anthelmintic drugs. Vet J, 154:11-34, (1997). 
16. Mali RG,Wadekar RR.,In vitro Anthelmintic activity of Baliospermum montanum Muell.Arg roots.Indian J Pharm. Sci, 70: 131-133, (2008).

17. Rastogi S, Kulshreshtha DK, Rawat AKS, Streblus asper Lour. (Shakhotaka): A review of its chemical, pharmacological and ethnomedicinal properties. Evid. Based Complement Altern. Med, 2006; 3: 217-222.

18. Gaitonde BB, Vaz, AX, Patel JR, Chemical and pharmacological study of root bark of Streblus asper Lour. Indian J. Med. Sci, 1964; 18: 191-199.

19. Khare MP, Bhatnagar SS, Schindler O, Reichstein T. Die glykoside von Streblus asper Lour. Helv Chim Acta, 1962; 45: 1515-34.

20. Khare MP, Bhatnagar SS, Schindler O, Reichstein T. Die glykoside von Streblus asper Lour. Helv Chim Acta, 1962; 45: 1534-46.

21. Jain SK. Dictionary of Indian Folk Medicine and Ethnobotany, New Delhi: Deep Publications, 1991; 172.

22. Kirtikar KR, Basu BD. Indian Medicinal Plants, Allahabad: Lalit Mohan Basu Publications, 1933; 3: 2291.

23. Ibrahim NM, Ishak M, Vuanghao L, Ahmad R, Antioxidant Activity and Phenolic Content of Streblus asper Leaves from Various Drying Methods, Antioxidants, 2013; 2: $156-166$.

24. J. A. Pereira, I. Oliveira and A. Sousa et al., Walnut (Juglans regia L.) Leaves, Phenolic Compounds, Antibacterial Activity and Antioxidant Potential of Different Cultivars, Food Chem. Toxicol., 45, 2287-95 (2007).

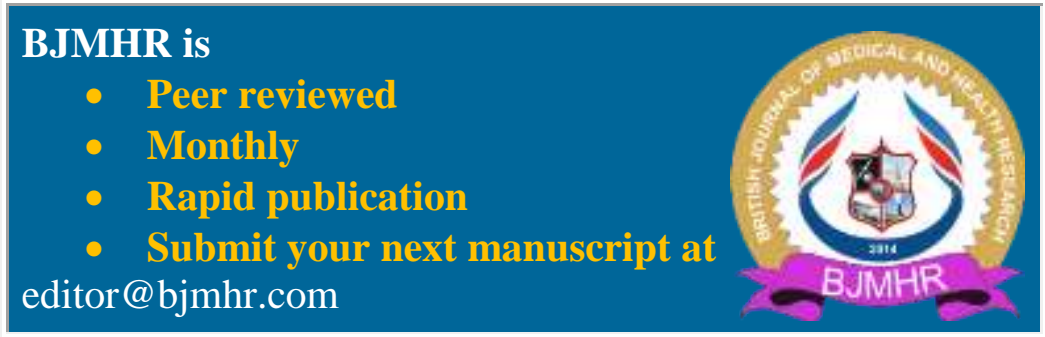

